\title{
8. Women-Owned SMEs in Supply Chains of the Corporate Resources Sector
}

\author{
Ana Maria Esteves
}

\section{Introduction}

The creation of economic opportunities through the development of small and medium enterprises (SMEs), and integration of these enterprises into the supply chains of large companies, has been promoted by international development agencies such as the International Finance Corporation (IFC) and the United Nations Industrial Development Organization (UNIDO). A strong SME sector is considered to provide social benefits such as the empowerment of local communities and a path out of poverty. In developing countries, SMEs are also considered to have a positive impact on regional income distribution. Their labour intensiveness with low technological and capital equipment requirements provides employment for relatively disadvantaged members of the community, such as women with reproductive and household duties, the unskilled and the elderly (UNIDO 2003, Nelson 2007).

Reinforcing the message of the development agencies is a growing recognition within mining, oil and gas companies of the uneven revenue distribution and limited employment opportunities offered by the sector (Esteves and Vanclay 2009). This has led to some consideration of the social and economic value potentially realised though the sourcing, sub-contracting and procurement of goods and services from local small enterprises. The management complexities of what is commonly referred to as 'local content' are numerous. Companies increasingly face contractual obligations under host country agreements for local content and social investment. However, local SMEs are often excluded from procurement processes, due to the large scale of contracts, inaccessible procurement systems and complex technology, safety, labour and reporting requirements. Where local content is pursued, activities are often constrained by infrequent management attention, market failures and governance gaps (ODI 2005; Wise and Shtylla 2007).

Adding to the disadvantage encountered by SMEs is the perception among financial institutions or potential investors that SMEs are high risk borrowers or low profit investments, and are typically characterised as having insufficient 
assets and low capitalisation, and therefore vulnerable to market variability. The shortcomings are weighted with associations with high mortality rates, lack of accounting records and business plans and high transaction costs (UNCTAD 2004, Ruffing 2006).

Women entrepreneurs face additional restrictions: cultural values and social norms often limit equal participation in society; they have unequal access to productive resources and services, such as finance and skill upgrading; certain legal provisions and legislative systems prevent women from securing property rights (for instance the husband will have legal ownership of the business, even if the person responsible for running the business is a female), and they have reduced opportunities as a consequence of their reproductive role (De Groot 2001; UNIDO 2003). Literacy levels can be a major challenge in developing countries, where some traditional societies constrain the inclusion of females in entrepreneurship development. Mature women are more likely to have been excluded from formal education, reducing their chances of becoming formal entrepreneurs.

This chapter considers these issues by taking the perspective of corporate professionals seeking to address the following management challenge: how can supply chain value be enhanced through building the capacity of female entrepreneurs to participate in SME development activities, while also enhancing development benefits to local communities? The chapter commences with an overview of concepts related to 'local female content' as practiced by mining, oil and gas companies. The concepts are illustrated through an example involving a resources company operating in Ghana that has partnered with the IFC and a local business association to develop business linkage and mentoring programs. Finally, knowledge gaps in the supply chain management literature and corporate practice are highlighted.

\section{Integrating Concepts of Supply Chain Management and Women's Development}

The 'supply chain' is a relatively new management term and concept, having developed mainly as an extension of production and operations management over the past 20 years. Whereas production and operations management concentrated on the firm's efficiency, quality, service, delivery performance and other aspects of managing assets for performance, supply chain management recognises the importance of coordination and control across firms that are participating together in supplying a set of goods or services. Supply chain management considers that it is not only firms that produce and compete, but that 'chains' of companies that supply each other can be considered together, 
as a group of coordinated owners of assets locked into a mutually beneficial relationship. It refers to the flows of goods and services, information and money between inter-related partners in production of these outcomes.

The supply chain management literature points to numerous variables which influence the relationship between the company and prospective local suppliers. Those summarised by Croom et al. (2000) include:

- the sourcing strategy, for example, sole-sourcing, multi-sourcing, or partnering;

- the attitude and commitment to collaborative improvement programs;

- the positioning of the local firm within the total network;

- the extent of dependence on the network, measured as the proportion of a supplier's business which is dedicated to the supply network;

- the longevity of the relationships, for example, past behaviour, opportunism and trust in suppliers;

- the technological or process links, for example, if the supplier holds the equipment needed to make their customer's product, or the existence of electronic links to facilitate ordering and payment;

- the existence of legal ties, such as contracts or shared patents, for example;

- the degree of power and influence of each party,

- the length and complexity of the chain; and

- the distance from the end-customer (the greater the number of stages, the less an organisation will perceive its dependency upon end-user demand).

Supply chain and procurement managers typically promote and facilitate linkages with local firms by adopting a range of approaches. These have been discussed in some detail by Engineers Against Poverty (2007) and are as follows. The most common means of implementing local content policies is 'preferencing' specific companies or groups in the award of tenders. Typically, an enterprise will have the preference figure discounted from its tender price. South Africa has been one example, where Black Economic Empowerment (BEE) legislation was introduced to address inequalities created by past history. Under the legislation, many companies are obliged to procure preferentially from previously disadvantaged black-owned enterprises.

Another approach is 'set aside' or 'reservation'. Local SMEs can be disadvantaged or even excluded from supply chains as a result of the increasing industry trend to 'bundle' supply requirements into larger (and therefore fewer) contracts, in order to reduce transaction costs and enable suppliers to benefit from bulk discounts. Unbundling can allow goods and services deemed suitable for local supply to be set aside or reserved for local enterprises. 
Some companies prefer to incentivise and transfer many of their responsibilities for local content to a better-prepared lead contractor. 'Pushing' responsibility for local content down the supply chain can occur through the use of prequalification processes to ensure that major contractors have the required capabilities in capacity-building, subcontracting or partnering with local firms. At the tendering stage, companies can specify that potential contractors enter into a joint venture with a local enterprise, sub-contract portions of the contract to a local enterprise or source from local enterprises. Through tendering processes, companies can even preference large contractors that develop innovative approaches to maximising local enterprise involvement.

A further strategy involves adapting procurement processes so as to ensure their accessibility to local SMEs. This can be achieved by communicating future demand for goods and services to allow suppliers enough time to build the required capability and having longer contract periods to enable the acquisition of capital equipment. Tender processes can also be made more accessible by simplifying pre-qualification processes and tendering procedures, having appropriately translated and distributed tender documentation and offering training and assistance in the tender preparation process and to understand the company's standards and requirements. Supply chain managers and technical end users can also provide support to supplier development programs typically delivered by external organisations or dedicated internal units. Assistance is provided in focusing program activities through mapping future demand and establishing the criteria for assessing goods and services.

To ensure that women benefit from enterprise development opportunities arising from company operations, management approaches need to be examined from a gender-aware development perspective. Potentially, major resources companies provide a significant opportunity to stimulate the participation of women in local economies - by integrating SMEs with female ownership and employment into the corporate supply chain, and building the capacity of these SMEs to become competitive. However, economic growth does not affect men and women equally. Genderless approaches to SME development will ignore the complexities that underlie exchanges between women and men (Srinivasan and Mehta 2003). Any industry intervention that aims to bring the benefits of economic growth to women will require an understanding of women's vulnerability, their socio-cultural context, the institutional structures and processes within their communities and the strategies employed by women to manage their assets.

More consideration of 'what works' is warranted in this little researched area of practice. There has been limited empirical evidence of the promoted benefits of supply chain linkages to women's development. Typically, these linkage programs address areas such as financing, business management and technical 
skills development, and support and institutional strengthening activities to encourage an enabling environment and reduce gender gaps in legal, business and financial systems (De Groot 2001; ODI 2005; Wise and Shtylla 2007). The potential benefits of SME linkages for companies, SMEs and the local region have been described by Jenkins et al. (2007), Ruffing (2006), UNIDO et al. (2004) and UNCTAD (2001). However, not all linkages between major corporations and local SMEs have been shown to create beneficial development impacts. An UNCTAD (2001) report pointed out that the extent and nature of the impact depends on the amount of procurement a company sources from the region, the size of the company's activity relative to the regional economy and the socio-cultural, regulatory and political context. In highly protected economies, there is little incentive to upgrade suppliers' technology. This fosters supplier dependence, placing it at risk if the company goes through a downturn, changes procurement strategy or decides to decommission.

From a corporate perspective, while in theory SME linkages are beneficial by offering savings in delivery and price, lower labour costs associated with poor regions and the close proximity of local suppliers to a project; in reality, there are a number of issues. Attaining the necessary quality standards can be expensive and technical, business management, financial support and risk guarantees may be necessary (ODI 2005). In imperfect market conditions, the preferencing approach can lead to local enterprises charging monopolistic prices. With regard to the set aside approach, while it facilitates entry for SMEs, there are also disadvantages for companies, such as additional administrative costs, potentially reduced effectiveness of project management and increased contractual risk. A further issue affecting all local content approaches is the problem of token (also referred to as 'front') organisations being established in order to win business (Engineers Against Poverty 2007).

Companies also face internal pressures which discourage local content. An Overseas Development Institute (ODI) report (2005) showed how the industry trend towards global strategic sourcing has led to favouring low cost/high quality suppliers, which are often located in areas other than local communities. The report argued that local linkages are enabled by decentralised decision-making and local management with delegated authority for independent sourcing. Further, it is also often the case that enterprise development opportunities are managed by lead contractors rather than the company. Short-term, fixed price contracts can be barriers for lead contractors against participating in meaningful linkages activities. 


\section{Ahafo Linkages Program: Promoting Female Participation in Supply Chains}

There is general acceptance that developing competitive small enterprises requires coordinated intervention among the private sector, public sector, nongovernment organisations (NGOs) and public policy. As a result, a number of partnerships have emerged between governments, support institutions and development agencies to establish linkage programs. One such example of SME linkages in the resources industry is the Ahafo Linkages Program (ALP), Ghana; a partnership between Newmont Ghana Gold Ltd (NGGL) and the IFC. The brief overview and analysis of emerging issues provided in this section have been prepared drawing on NGGL documents and interviewing ALP staff.

NGGL Ahafo is a greenfield mine that commenced operation in July 2006. Located in the Brong-Ahafo region of Ghana in West Africa, the mine was the first largescale economic activity to be undertaken in the region. The region covers an area of just under 40000 square kilometres and accommodates approximately 1.8 million people who are historically reliant on subsistence farming and smallscale commercial farming. The area is known for the production of cocoa, timber and cashew (Newmont Ghana Gold Ltd 2009).

The development of the Ahafo mine has brought profound social and economic changes to local communities, such as access to new employment and economic opportunities, impacts to existing patterns of settlement and movement and increased demands on community representatives and social institutions, such as local government and civil society organisations (Kapelus and Rogers 2008). In a context of poverty, local expectations over the flow-on economic benefits from mine development are high. The presently low community capacity to service the needs of the mine creates tensions which the ALP in part has been designed to address. The ALP's goals are to maximise procurement of goods and services from seven affected communities, diversify local economic activity and provide management and technical skills training within and beyond the supply chain. Emphasis is placed on strengthening the Ahafo Local Business Association (ALBA). NGGL has a dedicated unit in the supply chain department to work with local suppliers. The internal unit is responsible for maintaining a database of pre-approved bidders for Newmont contracts, establishing local procurement procedures and obtaining internal 'buy-in' within the company for local procurement. The ALP assists in bringing pre-approved bidders up to Newmont standards.

While the ALP is still in the early stage of development, there is evidence pointing to increased economic benefits associated with the supply of goods and services to the mine to both men and women. Table 8-1 has drawn on a summary 
report prepared by ALP Program Management Office in January 2009, which included source data prepared by the NGGL Local Supply and Community Development unit). As shown in the table, the number of local SME suppliers in 2008 totalled 125. Participation of female-owned companies in Ahafo's local content amounted to 17 per cent, or 21 companies. This participation level increased from four companies in 2006.

Table 8-1: NGGL Ahafo Local Content Indicators 2006-2008.

\begin{tabular}{|c|c|c|c|}
\hline Indicator & $\begin{array}{c}\text { Baseline } \\
2006\end{array}$ & $\begin{array}{l}\text { Value } \\
2007\end{array}$ & $\begin{array}{l}\text { Value } \\
2008\end{array}$ \\
\hline Contracts awarded to local vendors (USD) & 1718949 & 4182654 & 4668404 \\
\hline $\begin{array}{l}\text { Contracts awarded to female local vendors } \\
\text { (USD) }\end{array}$ & 302003 & 707671 & 950537 \\
\hline $\begin{array}{l}\text { Proportion of contracts awarded to female } \\
\text { local vendors }(\%)\end{array}$ & 18 & 17 & 20 \\
\hline $\begin{array}{l}\text { Number of local vendors awarded with } \\
\text { contracts }\end{array}$ & 25 & 52 & 125 \\
\hline $\begin{array}{l}\text { Number of female local vendors awarded with } \\
\text { contracts }\end{array}$ & 4 & 13 & 21 \\
\hline $\begin{array}{l}\text { Proportion of female local vendors awarded } \\
\text { with contracts }(\%)\end{array}$ & 15 & 25 & 17 \\
\hline
\end{tabular}

Source: Author's own data.

The female participation indicators reported in the table show the natural evolution in local female content over a period of three years, 2006 to 2008. While the share of contracts awarded by NGGL to female-owned vendors has not varied significantly over this period (ranging from 17 per cent to 20 per cent), the number of female vendors has grown from four to 21 and the direct economic benefit to local female vendors has more than tripled. In 2008 the ALP decided to try and connect more women with ALP activities, thus ensuring equal access to business opportunities for both men and women. This reflected an attempt to increase total levels of local content, rather than increasing the share of available contracts to female vendors. Both male and female entrepreneurs were still required to go through the same screening and selection processes.

An assessment was conducted by ALP in early 2008 of women's economic activities and female entrepreneurs in the local area. As a result of these efforts, the company was able to access new local sources of goods and services. By December 2008, five female-owned companies had completed training with the ALP. One female-owned company (out of the 22) completed the Local Supplier Development training, which involved technical assistance to and mentoring of 18 females (representing 44 per cent of individuals). Local Economic Development training involved four female-owned companies (out of the 25) and training of 14 women (representing 56 per cent of individuals undergoing mentoring and 
training). By the end of 2008, ALP also participated in Institutional Capacity Building activities which involve Training of Trainers (two women out of the six local consultants hired to provide short-term training to ALBA members). In the same year, short-term training sessions were conducted for ALBA members in Financial Planning (six women among 35 participants), Basic Costing and Pricing (nine women among 29 participants) and Tender Management (six women among 30 participants).

At the time of writing this chapter, two out of three women had dropped out of the Local Supplier Development training program. No single dominant reason was identified by program staff: the lack of completion could have been attributed to the lack of basic levels of education, low levels of interest in running a business (an activity attributed lesser priority in the local traditional society) and the quality of mentoring. It was also noted by staff that the absence of strong formal entrepreneurship activity and prevalence of weak business practices are barriers which are not restricted to the women in the area. ALP had made some adaptations to the mentoring program in response, and more tangible results were being sought for the second group of program participants. A conclusion that could be drawn from this experience is that the absence of 'exit surveys' or another suitable evaluation mechanism means a missed opportunity to start tracking the program in terms of its broader social effects at the individual, family and community levels, and particularly its effects on gender equity.

A further challenge facing the ALP is the dependency of local suppliers on NGGL contracts, making them vulnerable to market fluctuations. The ALP is attempting to address this issue by providing assistance in diversifying the markets of companies being mentored. A new initiative, the Ahafo Business Week, involves a business fair promoting suppliers and entrepreneurial activity associated with the establishment of the NGGL Ahafo mine to other companies operating in the area. The first fair conducted in April 2009 involved 30 local businesses showcasing their products and services.

ALP staff also identified the need for more dissemination of ALP experiences. Capturing and communicating the learning is of particular significance when one considers the 2010 timeframe for IFC's exit from the ALP partnership. While a succession plan for a program manager is in place, NGGL has yet to make a decision as to the means by which the linkages program will be replicated. Two models being considered involve situating the program either within the company's internal community development unit, or at arms' length from the company under the Ahafo Sustainable Development Foundation. Both options present trade-offs as to program sustainability, community capacity-building orientation, and opportunities for corporate-community engagement. One of the drawbacks of not having a clear exit strategy is that the learning curve for 
those who will take over the management of the program will be steeper when the IFC exits than would have been the case if the exit strategy had been in place from the commencement of the ALP.

\section{Conclusion}

Corporate procurement and supply chain management provide the opportunity to address 'the female face of poverty' through sustainable enterprise development. However, there is a number of implementation issues faced by corporations. These are well known; for instance, Jenkins et al. (2007) have summarised the challenges in establishing linkages as: securing internal commitment; obtaining information about SMEs in the local market; measuring the impact (particularly societal impact) of linkages; managing community expectations; reducing the economic dependence of local SMEs on the company; building the skills and capacity of SMEs and improving access to finance. The management discipline would benefit by further research into strategies that assist managers in addressing these issues, selecting appropriate linkage strategies, and building an understanding of the enabling environment for sustainable local enterprise development.

Measuring the impact of linkages is a prominent gap within the resources sector. Here, the purchase of goods and services tends to be assessed in terms of their economic contributions to regions. These activities are rarely assessed in terms of their direct and indirect social impacts and potential development opportunities. A broader view of impacts is needed to build the empirical basis for informing management action (Esteves 2008), and to increase the capacity of managers in making decisions that enable local women to bid for and work within, and beyond, the resources sector. This is reinforced by increasing stakeholder expectations that companies demonstrate their impacts to the regions in which they operate.

Enhancing the development benefits to women will also require a shift from perceiving support for female-owned SMEs merely as a means of increasing the overall opportunities to entrepreneurs in affected regions (as is evident in the early stages of the ALP), to also being a means of addressing inequalities in households and communities. With this shift, gender-sensitive evaluations of SME program performance will become important; with indicators that are sensitive to local understandings of women's access to and control over resources, and that go beyond those explicitly stated by customary law. Such indicators are best developed through participatory approaches to program evaluation, where female entrepreneurs are involved in determining and evaluating the positive and negative effects on themselves, their households and livelihoods. 


\section{References}

Croom, S., P. Romano and M. Giannakis, 2000. 'Supply Chain Management: An Analytical Framework for Critical Literature Review.' European Journal of Purchasing and Supply Management 6: 67-83.

De Groot, T.U., 2001. 'Women Entrepreneurship Development in Selected African Countries.' Vienna: United Nations Industrial Development Organization (PSD Technical Working Paper 7). Viewed 3 January 2009 at http://www. unido.org/index.php?id=o4810

Engineers Against Poverty, 2007. 'Maximising the Contributions of Local Enterprises to the Supply Chain of Oil, Gas and Mining Projects in Low Income Countries: A Briefing Note for Supply Chain Managers and Technical End Users.' London: Engineers Against Poverty. Viewed 3 January 2009 at http://www.engineersagainstpoverty.org/news.cfm?cit_id=3989

Esteves, A.M., 2008. 'Mining and Social Development: Refocusing Community Investment Using Multi-Criteria Decision Analysis.' Resources Policy 33(1): 39-47.

Esteves, A.M. and F. Vanclay, 2009. 'Social Development Needs Analysis: Adapting SIA Methods to Guide Corporate-Community Investment in the Minerals Industry.' Environmental Impact Assessment Review 29(2): 137-45.

Jenkins, B., A. Ahalkatsi, B. Roberts and A. Gardiner, 2007. 'Business Linkages: Lessons, Opportunities and Challenges.' Cambridge: IFC, International Business Leaders Forum and the Kennedy School of Government, Harvard University. Viewed 3 January 2009 at http://www.hks.harvard.edu/m-rcbg/ CSRI/publications/report_16_BUSINESS\%20LINKAGESFINAL.pdf

Kapelus, P. and G. Rogers, 2008. 'Global Community Relations Reviewed: Site-based Assessment of Ahafo Mine, Ghana.' Oxford: Synergy Global Consulting. Viewed 26 April 2009 at http://newmontghana.com/index. php?option $=$ com_content $\&$ task $=$ view $\&$ id $=224 \&$ Itemid $=2$

Nelson, J., 2007. 'Building Linkages for Competitive and Responsible Entrepreneurship.' Cambridge: UNIDO, Harvard University. Viewed 3 January 2009 at http://www.unido.org/fileadmin/user_media/ Services/PSD/CSR/ Building_Linkages_for_Competitive_and_Responsible_Entrepreneurship. pdf

Newmont Ghana Gold Ltd, 2009. 'Ahafo Mine.' Viewed 3 January 2009 at http:// newmontghana.com/index.php?option $=$ com_content\&task $=$ view $\& i d=12 \&$ Itemid $=35$ 
ODI (Overseas Development Institute), 2005. 'Levers and Pulleys: Extractive Industries and Local Economic Development-Incentivising Innovation by Lead Contractors Through Contract Tendering.' London: ODI (Briefing Note 3). Viewed 3 January 2009 at http://www.odi.org.uk/resources/specialist/ business-development-perfomance-briefings/3-extractive-industries-localeconomic-development.pdf

Ruffing, L., 2006. Deepening Development through Business Linkages. New York: United Nations.

Srinivasan, B. and L. Mehta, 2003. In H.A. Becker and F. Vanclay (eds), The International Handbook of Social Impact Assessment: Conceptual and Methodological Advances. Cheltenham: Edward Elgar.

UNCTAD (United Nations Conference on Trade and Development), 2001. World Investment Report 2001: Promoting Linkages. New York: United Nations.

—, 2004. 'Business Linkages: Roster of Good Practices.' Geneva: UNCTAD.

UNIDO (United Nations Industrial Development Organization), 2003. A Path out of Poverty: Developing Rural and Women Entrepreneurship. New York: UNIDO.

UNIDO, Deloitte, The Global Compact and UNDP, 2004. 'Partnerships for Small Enterprise Development.' London and Washington: Deloitte Touche Tohmatsu Emerging Markets Ltd. Viewed 3 January 2009 at http://www. unido.org/index.php?id=044527

Wise, H. and S. Shtylla, 2007. 'The Role of the Extractive Sector in Expanding Business Opportunity.' Cambridge: Harvard University (M.A. thesis). Viewed 3 January 2009 at http://www.hks.harvard.edu/m-rcbg/CSRI/publications/ report_18_EO\%20Extractives\%20Final.pdf 